\title{
Testing Phytolith Analysis Approaches to Estimate the Prehistoric Anthropogenic Burning Regime on the Central California Coast
}

\author{
Rand R. Evett and Rob Q. Cuthrell \\ Corresponding author: \\ Dr. Rand Evett \\ Division of Ecosystem Science \\ Department of Environmental Science, Policy, and Management \\ 137 Mulford Hall \\ University of California \\ Berkeley, CA 94720-3114 \\ 707-538-7869 \\ revett@sonic.net \\ Additional author: \\ Dr. Rob Q. Cuthrell \\ Department of Anthropology \\ University of California, Berkeley, CA 94720 \\ (rcuthrell@berkeley.edu)
}

\begin{abstract}
Expanding on a previous study that used phytolith analysis and other evidence to show that native people within Quiroste Valley on California's Central Coast used frequent fire to actively manage vegetation by arresting succession toward shrubs or forest to maintain open grassland during the Late Holocene, we extracted phytoliths from soils at sites located on a $500 \mathrm{~m}$ grid throughout the coastal portion of the watershed. We found that the prehistoric grass-dominated grassland, likely maintained by frequent anthropogenic fire, extended to the landscape scale, well beyond the confines of Quiroste Valley. In a novel attempt to use the proportion of burned phytoliths in the soil to quantitatively estimate prehistoric fire frequency at nearby McCabe Canyon in Pinnacles National Park, we tested three approaches described in the phytolith literature to identify individual burned soil phytoliths and found each approach had serious problems. The first approach, identifying visually darkened phytoliths, was accurate when performed on freshly burned leaf material, but highly problematic when applied to weathered phytoliths extracted from a typical grassland soil. The second approach, using changes in the refractive index caused by heating of phytoliths, was not effective within the temperature range typical of grassland fires, and was prone to rehydration effects in the soil environment. The third approach, using Raman spectroscopy to identify phytoliths with spectral changes caused by heating of carbon occluded in phytoliths, was not able to distinguish heated, non-darkened phytoliths, but was able to distinguish visually darkened phytoliths that had been subjected to an open flame. Each approach was rejected as inadequate; we were unable to use phytoliths to quantitatively estimate prehistoric fire frequency. Additional research quantifying the effects of weathering on soil phytolith coloration and opacity may make the visual approach viable.
\end{abstract}




\section{Introduction}

\subsection{Phytolith analysis as an important component of a multidisciplinary study}

Phytolith analysis is a powerful tool that has successfully answered questions posed by researchers in numerous archaeological and paleoecological studies worldwide. However, interpretation of phytolith data becomes more powerful and robust when combined with other lines of evidence. A multidisciplinary team of researchers took advantage of this synergy while conducting an integrative historical ecological study of native people on California's central coast (Lightfoot et al. 2013) which investigated the hypothesis that native people at Quiroste Valley Cultural Preserve (QVCP) used fire to actively manage vegetation at the landscape scale from the Late Holocene to the time of Spanish colonization.

The climate and geology at QVCP dictate that grasslands will convert to woody vegetation types in the absence of relatively frequent disturbance (Ford and Hayes 2007; Cuthrell 2013b). Prior to European colonization, landscape fire was the only disturbance with sufficient scale and impact to maintain extensive grasslands in near-coastal areas. Natural lightning fires are rare in this region due to very low lightning frequency, with expected natural fire return intervals on the scale of approximately 100 years. In contrast, early ethnographic reports and historical accounts from many parts of California suggest indigenous groups burned their landscapes every 1-10 years. At QVCP, if indigenous people burned frequently, plant community succession would have been arrested, favoring grassland at the expense of shrubland and Douglas fir forest. If anthropogenic burning was infrequent or absent, landscape vegetation would have followed normal successional pathways and been dominated by woody vegetation types, except for brief intervals immediately following infrequent landscape-scale fires. 
Phytolith evidence in the QVCP study converged with archaeobotanical evidence (Cuthrell 2013a, 2013b), pollen and microscopic charcoal evidence (Cowart and Byrne 2013; Cowart 2014), geomorphological evidence (Cuthrell et al. 2013), analysis of faunal remains (Gifford-Gonzalez et al. 2013), historical accounts (Cuthrell 2013a), and tree-ring fire-scar evidence (Striplen 2014) to strongly support the hypothesis that anthropogenic fire was frequent and widespread in the valley. Soil samples collected along transects on the Quiroste Valley floor showed very high phytolith concentrations (most sites $>1 \%$ soil dry weight), dominated by grass phytolith morphotypes (Evett and Cuthrell 2013). Phytolith content within the valley is much higher than most other grassland sites sampled in interior California, but consistent with nearby coastal areas (Evett and Bartolome 2013). These data suggest that long-term, grass-dominated grasslands were widespread in Quiroste Valley prior to European colonization. At CA-SMA113, a significant archaeological site located in QVCP that was occupied during the Late Holocene and Early Historic periods, midden deposits (i.e., organic-rich layers containing shell, bone, and other artifacts formed through long-term occupation) were enriched in phytolith content compared to off-site soils at equivalent depths, indicating site inhabitants brought grasses and/or sedges to the site for use in crafting, construction, kindling, or for other purposes (Cuthrell 2013a; Evett and Cuthrell 2013). Within midden deposits, excavators recovered intact ash lenses, probably formed through hearth cleaning, that represent shorter-term episodes of burning. Quantifying phytolith content in ash lenses allowed researchers to determine whether fuels were primarily wood (few phytoliths) or whether fuels also contained substantial quantities of grasses (abundant phytoliths). The high phytolith content (1-5\% dry weight) in several ash deposits suggested that site inhabitants occasionally burned large quantities of grasses and/or sedges 
during relatively short episodes, perhaps as kindling or fuel, or to dispose of the byproducts of food or crafting activities (Evett and Cuthrell 2013).

Phytolith analysis can potentially contribute additional important information to the multidisciplinary effort at QVCP. First, sampling soil phytoliths from a much larger area outside the valley can provide important context for the extent of anthropogenic grasslands in the region at the landscape scale. Because few commonly occurring plant taxa in California except grasses produce large quantities of phytoliths and short cell morphotypes are unique to grasses, phytolith analysis has been very successful identifying the spatial extent of long-term grass cover in California (Evett et al. 2006; Evett et al. 2007; Evett and Bartolome 2013; Evett et al. 2013). By measuring soil phytolith content and performing absolute counts of grass phytoliths in soil samples collected from a grid overlaid on the larger watershed surrounding QVCP, phytolith analysis can be used to map the extent of anthropogenic grasslands and show how QVCP fits into the larger vegetation landscape. Second, distinguishing burned from unburned phytoliths in the soil may enable estimation of prehistoric long-term fire frequency in grassland environments, a potentially highly useful contribution to the research effort. Third, new methods of quantitative analysis of phytolith morphotypes may enable identification of grasses utilized by the native population to the genus or species level (Evett and Cuthrell 2015). Our objectives in this study are to shed light on the first two topics.

\subsection{Using phytolith analysis to derive quantitative estimates of prehistoric fire regimes}

Despite considerable qualitative information regarding Native American fire regimes in Californian grasslands and shrublands, primarily derived from ethnographic interviews of tribal elders, obtaining quantitative data to test hypotheses of fire frequency and intensity has been 
problematic because a lack of trees and lakes in these environments renders typical approaches such as fire-scar dendrochronology and charcoal analysis of lake sediments unfeasible (Stephens et al. 2007). Recent publications in the phytolith literature, which suggest it is possible to reliably identify phytoliths that have been subjected to fire, provide the framework for a promising, but to this point incomplete and untested, new approach to reconstructing prehistoric grassland fire regimes.

Because opal phytoliths are formed in grasses at a relatively constant annual rate and are highly resistant to decomposition, often persisting in the soil for hundreds or thousands of years after initial deposition (Wilding 1967), if burned phytoliths can be reliably differentiated from unburned phytoliths, the percentage of burned phytoliths in the soil phytolith assemblage could be developed for use as an index of long-term fire frequency at a site. Recent research suggests that several changes occur to phytoliths when they are heated or exposed to fire that would allow them to be distinguished from unburned phytoliths:

1) Phytoliths (normally transparent) change color, becoming dark or opaque (Parr 2006)

2) The refractive index (RI) increases; the ratio of phytoliths with $\mathrm{RI}>1.44$ to those $<1.44$ is $>1$ for burned phytolith samples (Elbaum et al. 2003)

3) The nature of chemical bonds between carbon molecules occluded in phytoliths, measured by spectra from Raman spectroscopy (focusing a laser beam on individual phytoliths), permanently changes as a function of maximum temperature exposure (Pironon et al. 2001).

Although these approaches have not been adequately tested and calibrated for quantitatively estimating long-term fire frequency from soil samples, each has been used to identify individual burned phytoliths. The first approach, using changes in the proportion of 
darkened phytoliths to total phytoliths in the soil profile, has been used by numerous researchers to qualitatively infer changes in fire frequency over time (Kealhofer 1996; Boyd 2002; Gu et al. 2008; Morris et al. 2010; Cordova et al. 2011; Garnier et al. 2012; McMichael et al. 2012; Jones et al. 2013; Aleman et al. 2014; Selkin et al. 2015). The second approach has been used successfully by archaeologists to identify phytoliths burned at high temperatures in hearths (Elbaum et al. 2003). The third approach has been demonstrated on modern and fossil phytoliths in the laboratory but has not been applied since the original publication (Pironon et al. 2001).

\subsection{Study objectives}

1) Because phytolith data for the initial QVCP multidisciplinary study was limited to the valley floor, the first objective of this study was to better understand prehistoric vegetation at the landscape scale by extracting phytoliths from soil samples at sites within the larger watershed surrounding the valley. Was the grass-dominated vegetation at Quiroste Valley an anomaly or was this typical of the surrounding landscape?

2) The second objective was to expand the utility of phytolith analysis by developing a quantitative approach to estimate fire frequency in grasslands. We tested the ability of the three published approaches described above to differentiate burned from unburned phytoliths obtained in lab experiments and from a prescribed grassland burn in the field, as well as phytoliths

extracted from the soil and an archaeological site. The goal was to calibrate the percentage of burned phytoliths in soils under grassland with known fire frequency and use this as an index to estimate fire frequency at other grassland sites, such as the landscape around QVCP.

\section{Regional setting}


The first study location is the region surrounding Quiroste Valley Cultural Preserve (QVCP), located about $5 \mathrm{~km}$ north of Point Año Nuevo, California (Fig. 1). In California's highly seasonal Mediterranean climate, this area receives the majority of its annual precipitation (ca. $65-90 \mathrm{~cm} / \mathrm{y}$ ) during the months from October through April (Cuthrell 2013a). In the local region around Quiroste Valley, monthly temperature means range from $\sim 10^{\circ} \mathrm{C}$ in December to $18^{\circ} \mathrm{C}$ in August, and freezing temperatures are rare. Except in places where poor soil conditions or salt spray prevent establishment of woody vegetation, northern coastal scrub, mixed conifer forests, redwood forests, maritime chaparral and oak woodlands are the climax vegetation types in the western portions of the Santa Cruz Mountains and adjacent coastal terraces. Quiroste Valley is currently dominated by Douglas fir, northern coastal scrub, and riparian vegetation, but historical evidence indicates current vegetation is recent and the result of succession; much of the valley was used for livestock grazing and farming (with no record of grain cultivation) during most of the $19^{\text {th }}$ and $20^{\text {th }}$ centuries (Cuthrell 2013a). In the absence of disturbance factors, between 1982 and 2012 grassland cover in the vicinity of Quiroste Valley shrank from 38.4\% to 12.8\% of vegetation cover (Cuthrell 2013a, 2013b). The floor of Quiroste Valley is composed of Holocene alluvium, while adjacent foothills represent uplifted Pleistocene marine terraces transformed by the San Gregorio fault zone (Cuthrell et al. 2013).

The second study location is McCabe Canyon, a recently acquired area within Pinnacles National Park (Fig. 1). While precipitation seasonality is similar to QVCP, its more inland location is drier with more extreme temperatures: precipitation averages $43 \mathrm{~cm} / \mathrm{y}$, mean December temperature is $8{ }^{\circ} \mathrm{C}$ and $22^{\circ} \mathrm{C}$ in August. Vegetation types include chaparral, riparian, and grassland. We focused on two areas within the canyon that have sizable patches of two species likely used by Native Americans for basketry and likely maintained by regular burning: 
deergrass (Muhlenbergia rigens, with saddle-shaped short cells found only in Muhlenbergia among common native California grasses) and whiteroot sedge (Carex barbarae, with conical cells only found in Cyperaceae).

\section{Materials and methods}

\subsection{Grid survey of soil phytoliths at sites surrounding Quiroste Valley}

Near-surface soil samples were collected from 23 sites located near the intersections of a $500 \mathrm{~m}$ grid overlaid on the coastal portion of the Whitehouse Creek watershed, which contains QVCP. Sampling locations included hillsides, valley floors, riparian zones, marine terraces, and dunes. To collect these samples, surface vegetation was scraped away to expose mineral soil; 50$100 \mathrm{~g}$ of soil was collected from the upper $2 \mathrm{~cm}$ (presumably the top of the A horizon) with a trowel at each location. Phytolith extraction procedures followed established protocols, including deflocculation, clay removal, microwave digestion of organic materials (Piperno 2006), and heavy liquid flotation (Evett and Cuthrell 2013). Soil phytolith extracts were dried, weighed, suspended in a measured quantity of immersion oil to enable absolute counts (Evett and Cuthrell 2013; Evett et al. 2013), and mounted on glass slides for examination in transects at 400x magnification under a light microscope. At least 200 phytoliths were counted and classified into general morphotype categories.

\subsection{Using burned phytoliths to quantitatively estimate grassland fire frequency}

To examine the effects of heating and burning on phytoliths of deergrass, we conducted both laboratory and field experiments. Laboratory work involved heating dried vegetative samples in a muffle furnace to temperatures at $100^{\circ} \mathrm{C}$ intervals from $100-600^{\circ} \mathrm{C}$, spanning the 
range of temperatures expected for a typical grassland fire (Gibson et al. 1990). Additional samples were burned using an open flame in a beaker under the laboratory hood. Portions of heated and burned samples were further processed in $6 \%$ sodium hypochlorite (household bleach), adjusted to $\mathrm{pH} 8$ (Siregar et al. 2005), for two days to remove residual organic matter without further heating (no visual evidence of phytolith corrosion due to this treatment was observed); both unprocessed and processed samples were rinsed several times in distilled water, air-dried, and suspended in immersion oil.

To examine evidence of burning through changes in phytolith color or opacity, single drops of phytolith suspension from both processed and unprocessed samples were placed on microscope slide and examined in transects under a light microscope at 400x magnification. The proportion of phytoliths showing evidence of burning was estimated by counting 300 phytoliths belonging to general morphotype categories for each sample (Table 1).

To investigate changes in the refractive index of phytoliths occurring as a result of heating, a portion of each processed phytolith extract was dried and then re-suspended in Cargille Refractive Index Liquid with refractive index 1.44. A drop of each suspension was placed on a slide and examined under a light microscope. By observing the nature of the Becke line (Elbaum et al. 2003; Wyche 2012), 200 saddle short cell phytoliths from each sample were counted and classified as either above or below $1.44 \mathrm{RI}$, and the percentage of phytoliths above 1.44 RI was calculated.

Following the procedure of Pironon et al. (2001), Raman spectrometry was performed using two instruments, a Renishaw RM1000 at the Spectral Imaging Facility at University of California, Davis, and a confocal Horiba LabRAM HR at the Analytical Chemistry Instrumentation Facility at University of California, Riverside. A drop of aqueous suspension of 
each phytolith sample was placed on a piece of aluminum foil taped to a slide (to avoid contamination with the spectrum of the glass slide, which is composed of amorphous silica similar to phytoliths; adopted after failed attempts to replicate Pironon et al. (2001), who placed dried phytolith powder directly on a glass slide), allowed to dry, and then placed under the microscope. Individual phytoliths were located on each slide and the laser beam focused within the phytolith at 1000x. Samples were examined using two laser light wavelengths, $523 \mathrm{~nm}$ and $784 \mathrm{~nm}$. Raman spectra were obtained for dozens of phytoliths from each sample using a wide range of confocal aperture widths and exposure times ranging from 10 seconds to 2 minutes (Pironon et al. (2001) reported an exposure time of 2 minutes with an unreported aperture using a $514 \mathrm{~nm}$ laser). Raman spectra of individual phytoliths were closely examined to identify predictable spectral patterns expected to manifest with increasing temperature.

The field portion of the study had several components. At the deergrass site in McCabe Canyon, soil samples and specimens of major plant species occurring in the area were collected prior to a prescribed burn in December 2011 and phytoliths were extracted following established phytolith sampling procedures (Evett et al. 2006; Evett et al. 2007) to establish a baseline soil phytolith assemblage, with interpretation based on a modern phytolith reference collection. Prior to the burn, aluminum tags painted with temperature-sensitive lacquers from $79-204^{\circ} \mathrm{C}$ (Tempilaq) were placed in previously delineated sample plots in order to estimate the range of maximum temperatures occurring during the burn. Samples of ash were collected from each plot immediately following the burn. These were examined under the microscope at 400x before and after treatment with bleach to determine the proportion of visually darkened phytoliths resulting from the burn. To estimate the rate of incorporation of burned phytoliths into the soil after two rainy seasons following the burn, soil samples were collected from each plot late spring 2013, 
phytoliths extracted and burned phytoliths counted. Phytoliths extracted from soils at selected sites and archaeological features during previous studies at Quiroste Valley and Pinnacles National Park were also examined and burned phytoliths counted.

Rather than assume the percentage of burned phytoliths in a soil phytolith assemblage produces a reasonably accurate quantitative estimate of long-term fire frequency, we also attempted to test and calibrate this approach by extracting soil phytoliths from ponderosa pinebunchgrass sites along a fire frequency gradient in the Rincon Mountains of southern Arizona. These sites were chosen because there are fire frequency maps constructed from welldocumented historical and dendrochronological fire histories extending back several hundred

years that document relatively stable fire frequencies continuing through the present, a highly unusual situation given the introduction of fire suppression in most forests $100+$ years ago (Farris et al. 2010). Sample sites were located within patches of grass in the forest (because the presumed long-term grass understory in the pine forest was expected to produce abundant burned phytoliths for analysis). Sites were located within zones of fire frequency (delineated on a map published by Farris et al. 2010) ranging from $<10 \mathrm{yr}$ fire return interval to $>100$ years since the last fire; two soil samples were collected at each site and soil phytoliths were extracted and analyzed as described above.

\section{Results and discussion}

\subsection{Grid survey of soil phytoliths at sites surrounding Quiroste Valley}

Sampling locations and soil phytolith content (percent soil dry weight) at sites on the 500 $\mathrm{m}$ grid around QVCP are presented in Fig. 2. Phytolith content was consistently high in the entire coastal portion of Whitehouse Creek watershed, ranging from $0.2-2.1 \%$, with a mean of $1.08 \%$ 
and an interquartile range of $0.6-1.6 \%$ (Fig. 2; Table 1). Soil phytolith content throughout the grid was generally much higher than the $0.3 \%$ threshold used to designate likely long-term grassdominated grasslands in California (Evett and Bartolome 2013; Evett et al. 2013). Sites with soil phytolith content $<0.7 \%$ were mostly located in developed areas or sandy soils associated with dune fields near the coast, although two sites with low phytolith content $(0.20$ and $0.43 \%)$ were located on hillsides. These areas may have been modified from natural causes such as landslides or historic land use practices that removed the phytolith-rich near-surface soils observed elsewhere in the watershed.

The climax vegetation currently found at QVCP, particularly northern coastal scrub and riparian, does not include species that contribute substantial phytolith input to the soil. While Douglas fir does produce phytoliths (Evett et al. 2013), very few phytoliths diagnostic of Douglas fir were observed in any of the soil phytolith assemblages examined. High phytolith content in QVCP soils, similar to elsewhere in California (Evett and Bartolome 2013), likely indicates the long-term presence of grass-dominated grasslands. Previous research in California, based on research examining phytolith deposition and dissolution in the Great Plains (Blecker et al. 2006), has estimated that soil phytolith content in coastal California represents at least several hundred to more than a thousand years of accumulation (Evett and Cuthrell 2013; Evett et al. 2013), Phytolith input from historical land use practices during the past 200 years, even if they involved land clearing and conversion to grasses for grazing or grain cultivation, would only have contributed a small fraction of the current phytolith content in Quiroste Valley soils.

Absolute counts of soil phytolith morphotypes also indicate most of the landscape was dominated by grasses, strongly reinforcing the soil phytolith content data (Table 1). Total grass short cell content at 22 of the 23 sites is $>200,000 / g$ soil, indicative of long-term grass-dominated 
grassland (Evett and Bartolome 2013). The only site below the threshold may have been longterm grassland but phytolith content in the sandy soil at this site near the coast may have been affected by differential migration of smaller short cell phytoliths (Fishkis et al. 2010). The majority of sites contained $>1,000,000$ short cells/g soil, similar to the high counts indicative of overwhelming grass dominance observed in near-surface soils along transects within Quiroste Valley (Evett and Cuthrell 2013). The highest short cell counts (mostly >1,800,000/g soil) occurred in soils in the southeast corner of the grid.

Of particular interest was a trend toward a higher ratio of bilobate short cells to total phytoliths near the coast (Table 1). In coastal California, bilobates are not indicative of panicoid grasses, but are diagnostic for the presence of two native, non-panicoid grass genera: Stipa and Danthonia (Evett et al. 2013). While bilobates were common at most sites within Quiroste Valley (Evett and Cuthrell 2013), they were comparatively much more abundant in soils near the coast. While both genera are found in the study area, increasing bilobate abundance near the coast suggests that Danthonia species, better adapted to more mesic conditions, were dominant there.

The landscape-scale data provided by the $500 \mathrm{~m}$ grid survey confirm that most of the area surrounding QVCP was covered with grass-dominated grassland vegetation. Quiroste Valley was not an isolated oasis of grass, but rather a small part of much more extensive grassland in this region of the central California coast. These results suggest the conclusion reached by the Quiroste Valley phytolith study applies at the landscape scale: based on the phytolith data, frequent anthropogenic fire is the most likely explanation for the extensive, long-term, grassdominated prehistoric grassland. 


\subsection{Using burned phytoliths to quantitatively estimate grassland fire frequency}

\subsubsection{Temperatures recorded during McCabe Canyon prescribed burn}

The prescribed burn at the deergrass site in McCabe Canyon was very patchy. While most of the site showed evidence of burning, there was a wide range of charring of vegetation and ash production (Fig. 3). Precise measurement of maximum temperatures achieved during the prescribed burn was not successful. At all but one of the plots, all of the temperature-sensitive lacquers melted on the aluminum tags, indicating the prescribed burn was considerably hotter than expected. The range of temperatures measured by the lacquer clearly needed to be much higher.

However, based on deergrass leaf samples that were exposed to a range of temperatures in the muffle furnace in the laboratory, an indirect method of estimating fire temperature using the color of the burned leaves was devised. Leaves and stems heated to $300^{\circ} \mathrm{C}$ in the muffle furnace maintained their structure but showed considerable, incomplete black charring. Samples heated to $400^{\circ} \mathrm{C}$ showed complete black charring with some breakdown of leaf structure. At $500^{\circ} \mathrm{C}$, samples were reduced to fine black ash, converting to fine white ash at $600^{\circ} \mathrm{C}$. Using these parameters, an ocular estimate of the percentage area of the burn within each temperature class was: $15 \%$ from $0-200^{\circ} \mathrm{C}, 20 \%$ from $200-400^{\circ} \mathrm{C}, 10 \%$ from $400-500^{\circ} \mathrm{C}$, and $55 \%>500^{\circ} \mathrm{C}$.

Because almost all of the aluminum tags were placed within individual deergrass plants where post-fire ash indicated the fire temperature was $>500^{\circ} \mathrm{C}$, it is not surprising their narrow temperature range failed to record fire temperatures. Two tags showed evidence of melted aluminum. Because the melting point of aluminum is $660^{\circ} \mathrm{C}$, maximum temperatures at the site during the burn likely approached $700^{\circ} \mathrm{C}$, considerably hotter than maximum temperatures 
recorded in grassland fires in Kansas and Florida (Gibson et al. 1990). This may have been due to the extensive thatch buildup in the deergrass plot that had likely not been burned for decades.

\subsubsection{Using phytolith coloration to identify burned phytoliths}

Deergrass and ponderosa pine leaf samples burned with an open flame in a beaker in the laboratory produced high percentages of phytoliths that were either opaque black or transparent but dark gray or dark brown (Table 2; Fig. 4A). A few phytoliths showed no color change as evidence of burning, even though they were in close proximity on the same leaf as phytoliths that changed color (Figs. 4B, 4C). Identifying phytoliths as positively burned or unburned was a relatively simple task using burned leaf material, although a small percentage of phytoliths appeared very light gray or brown and were classified as possibly burned (Table 2; Fig. 4C). Almost all grass short cells showed obvious color changes after burning, even in leaf fragments where elongates remained clear (Fig. 4C).

Deergrass leaf samples heated in a muffle furnace did not produce phytoliths with evidence of burning below $400^{\circ} \mathrm{C}$, and only minimal percentages of burned or possibly burned phytoliths at $500^{\circ} \mathrm{C}$ or $600^{\circ} \mathrm{C}$ (Table 2). Leaf samples heated above $300^{\circ} \mathrm{C}$ in the muffle furnace often smoldered rather than ignited, with flames only appearing briefly; the low percentages of burned phytoliths observed in these samples may reflect the brief flaming episodes. Exposure to an open flame rather than heat may be required to produce darkened phytoliths, contrary to the assertion of Pironon et al. (2001).

Samples of ash taken from plots immediately after the prescribed burn in McCabe Canyon had high percentages of darkened phytoliths indicating burning (Table 1). Because burned phytoliths in the ash appeared identical to the phytoliths from leaf material burned in the 
laboratory, there was little problem identifying color differences between burned and unburned phytoliths, although very lightly colored phytoliths were still problematic and classified as possibly burned.

Positively burned phytolith percentages of soil samples taken from plots in the deergrass site before and after the prescribed burn were not substantially different. Because most of the recently burned phytoliths were still on the surface and not enough time had passed to incorporate them evenly along the surface or at depth into the soil, these values may be highly dependent on sample location.

Samples of soil from all sites in the study contained high percentages of phytoliths classified as possibly burned (Table 2). These phytoliths show some alteration of color or opacity but they do not have the obvious black, gray, or brown darkening or reduced opacity seen in the laboratory burned or ash samples (Figs. 4D, 4E, 4F).

A major problem with identifying burned phytoliths in soil samples is that both burned and unburned phytoliths undergo taphonomy due to weathering and other processes over time in the soil (Madella and Lancelotti 2012; Cabanes et al. 2011). While there has been research suggesting burned phytoliths are more soluble in the soil than unburned phytoliths (Cabanes et al. 2011), there has been no research examining how weathering and other taphonomic processes change the color and opacity of burned phytoliths compared to unburned phytoliths. Based on examination of phytoliths extracted from hundreds of soil samples from sites throughout California (Evett and Bartolome 2013), the low percentages of positively burned phytoliths seen in soil samples in this study are typical, as are the high percentages of possibly burned phytoliths that show changes that may be due to burning, weathering, or both. 
Soil samples at sites in Pinnacles NP had few positively burned phytoliths (Table 2). A sample at $30 \mathrm{~cm}$ depth (age of this deposit is unknown) from a cut bank in an intermittent channel $\sim 100$ m below the deergrass burn site showed $56 \%$ of phytoliths may have been burned. Soil samples collected during a survey of current grassland areas in Pinnacles NP have lesser content of possibly burned phytoliths. A sample from a grassland area near the park entrance that was burned in 2009 has a positively burned phytolith percentage comparable to the post-burn deergrass plot (Table 2).

Given the low positively burned phytolith percentages in the soils examined, to better understand the effects of weathering on burned phytoliths, samples were examined from two sites that would be expected to have high burned phytolith percentages that had also been subjected to weathering. The first sample was obtained from an ash pit known to have very high phytolith content, deposited $\sim 1000 \mathrm{yr}$ ago at a Quiroste Valley archaeological site, CA-SMA-113 (Evett and Cuthrell 2013). While $81 \%$ of the phytoliths showed some alteration, only $11 \%$ were positively identified as burned (Table 1). The second sample was phytoliths extracted from soil formed on Reunion Island in the Indian Ocean composed largely of mascareignite, a mineral derived from burned bamboo phytoliths deposited during the past several thousand years (Meunier et al. 1999). This sample showed 57\% of the phytoliths had some alteration, but only $6 \%$ were positively burned. These results suggest that most of the altered phytoliths observed in soil samples from Pinnacles NP could plausibly be burned.

The most powerful argument against altered but non-darkened phytoliths being burned comes from the Raman spectroscopy portion of this study, which found only phytoliths that were obviously darkened, not those altered in other ways, produced Raman peaks characteristic of burning (see Raman results section). The lack of research on weathering effects on burned vs. 
unburned phytoliths remains an obstacle to application of this approach to reconstructing fire regimes.

Phytoliths extracted from soil samples collected along a fire frequency gradient from the Rincon Mountains in Arizona showed few that could be positively identified as burned (Table 2). All sites had total altered phytoliths (including both positively and possibly burned) between 30 $50 \%$, but there was no significant correlation between the fire return interval (FRI) and any measure of altered phytoliths. This suggests that most of the phytoliths classified as possibly burned were not burned, but rather only weathered, since all sites were subjected to the same weathering regime. Another possible explanation is that sites would need to have a FRI more frequent than 10-15 years to make enough impact on the soil phytolith assemblage to raise the positively burned phytolith level above background noise.

In summary, using phytolith coloration to identify burned phytoliths in the soil appears to have some potential as an approach for reconstructing past fire regimes or cultural burning practices, but the uncertainties involved currently prevent defensible interpretations. In addition, visual classification of burned vs. unburned phytoliths involves highly subjective decisions made by each researcher regarding what constitutes a burned phytolith, rendering the current approach unreliable and not replicable. For example, there has been no research on the effects of different phytolith extraction procedures on taphonomic effects, including subtle changes in phytolith coloration (Madella and Lancelotti 2012). While our burning experiments have demonstrated that a high percentage of phytoliths in leaves subjected to open flames change to a darker color, there are likely changes that occur to burned phytolith coloration following weathering in the soil that make them difficult to distinguish from weathered unburned phytoliths. However, most previous research utilizing darkened phytoliths as an indicator of burning has been conducted in 
low-weathering conditions, possibly mitigating this complicating factor. For example, Boyd (2002) examined phytoliths in loess deposits, where most phytoliths were buried below the biological weathering zone near the surface before much weathering occurred. Likewise, Kealhofer (1996) examined phytoliths in lake sediments where weathering is greatly reduced. On the other hand, researchers in a study of soil phytoliths in Utah made no mention of difficulty identifying burned phytoliths (Morris et al. 2010). However, burned phytolith percentages approaching 50\%, found at sites with a recent fire but no long-term history of frequent fires, are hard to understand unless pure ash was collected from the soil surface or many weathered but unburned phytoliths were counted as burned. Regardless, even if all altered phytoliths do indeed represent burned phytoliths (contrary to the Raman results), the Rincon Mountains data suggest that unless fires are very frequent, the percentage of burned phytoliths in the soil phytolith assemblage may not change much.

\subsubsection{Using refractive index to identify burned phytoliths}

There was little effect on the refractive index of phytolith samples heated for 10 minutes in a muffle furnace below $300^{\circ} \mathrm{C}$ (Fig. 5). Above $300^{\circ} \mathrm{C}$, the RI increased with increasing temperature. However, exposure to temperatures $>480^{\circ} \mathrm{C}$ were required to exceed the $50 \%$ above 1.44 RI threshold used by Elbaum et al. (2003) to identify a phytolith sample that had been burned. Additionally, there were substantial decreases in RI resulting from rehydration of heated phytoliths when immersed in water for one week (Fig. 5). Phytolith samples heated to higher temperatures exhibited increased rehydration effects. Rehydrated samples did not cross the $50 \%$ threshold unless initially heated to nearly $600^{\circ} \mathrm{C}$. 
The RI approach to identify burned phytoliths relies on the fact that heating of a phytolith exposed to fire expels some of the water that was incorporated in the phytolith matrix during its formation. Because the RI of water at $20^{\circ} \mathrm{C}$ is 1.33 and the RI of pure silica is 1.54 , the RI increases as more water is expelled at higher temperatures. However, our phytolith heating experiment shows there are several problems with trying to apply this approach to grassland fires:

1) There are no obvious changes in phytolith RI that occur unless heated above $300^{\circ} \mathrm{C}$. Many plants subjected to a typical grassland fire will not be heated above this temperature (Gibson et al. 1990) and will not record any changes in RI. This is particularly a problem for low intensity fires resulting from annual or biennial burning that may have characterized the Native American grassland burning regime in California.

2) Even if fire temperatures at a site routinely exceed $300^{\circ} \mathrm{C}$, the percentage of phytoliths recorded as burned depends on the patchiness of fire intensity. Areas at a site that burn hotter produce a higher percentage of phytoliths with RI $>1.44$. Using the percentage of phytoliths with RI $>1.44$ as an index for fire frequency is not accurate because of the confounding effects of fire intensity patchiness.

3) Changes in RI likely occur due to rehydration when a burned phytolith is incorporated into the soil and exposed to soil moisture. This suggests the percentage of phytoliths above $1.44 \mathrm{RI}$ in the soil phytolith assemblage as an index of fire frequency is confounded with the soil moisture regime.

4) The water content of phytoliths generally decreases with age (Piperno 2006), which means a phytolith that has persisted in the soil for hundreds of years will have a higher RI regardless of whether it was exposed to fire. Because a soil phytolith assemblage is 
composed of phytoliths along a continuum of ages and the age of an individual phytolith is unknown, this variable is also confounding.

The RI approach to detect burned phytoliths was developed to determine whether plants at an archaeological site were burned in a hearth context in which temperatures were expected to exceed $1000^{\circ} \mathrm{C}$ (Elbaum et al. 2003). For this situation, the problems outlined above are not as significant because all phytoliths are heated to temperatures that increase the RI. Fires in the hearth are hot enough to increase all phytolith RI well above 1.44 . While rehydration likely lowers burned phytolith RI, the majority would remain above the 1.44 threshold. Additionally, the phytoliths in an archaeological feature such as a hearth are likely of similar age, eliminating the problem of mixed-age assemblages encountered in soils.

Our experiment has shown that trying to apply this approach to identify burned phytoliths from grassland fires is highly problematic and using this approach to estimate grassland fire frequency and/or intensity is highly uncertain. Other techniques (such as Fourier Transform Infrared Spectroscopy) that rely on phytolith water content to identify burned phytoliths have the same problems and are likely unsuitable as well. Recent research with sponge spicules (Wyche 2012) has highlighted problems with using the refractive index to reliably identify heating of amorphous silica at temperatures below $700^{\circ} \mathrm{C}$. At the same time, this research suggests there may be predictable changes, not related to water content, occurring to the fluorescence spectra of biogenic silica when exposed to lower temperatures.

\subsubsection{Using Raman spectroscopy to identify burned phytoliths}

Because the phytolith coloration and RI approaches to positively identify phytoliths exposed to fire were found unsuitable for reconstructing grassland fire regimes, considerable 
time and effort ( 250 hours in the Raman lab and spectra of $\sim 1500$ phytoliths examined) were expended testing the Raman spectroscopic approach. While the procedure described by Pironon et al. (2001), focusing a laser anywhere within a burned phytolith to produce Raman peaks characteristic of graphite carbon, seemed straightforward and the results definitive, technical challenges were considerable and replicating their results proved problematic.

The first technical issue addressed using the UC-Davis Raman instrument was overcoming powerful background fluorescence inherent in individual phytoliths to obtain the much weaker Raman signal. To test whether the bleach extraction treatment was causing the high background, several other phytolith extraction procedures, as well as simple surface enhanced Raman techniques (aluminum foil treated with iodine) were tested, but almost all heated phytoliths examined still did not produce a Raman signal for carbon, and only a handful produced the Raman silica peaks that would be expected in objects largely composed of amorphous silica (Watling et al. 2011; Pironon et al. 2001). Pironon et al. (2001) used a relatively obscure sulfuric acid-based extraction procedure (Kelly 1990) to reduce background fluorescence. We tested this procedure and found the background fluorescence was reduced but the Raman signal of all except obviously darkened burned phytoliths was still too weak to be detected on the UC-Davis instrument.

Using the more sensitive confocal Raman instrument located at UC-Riverside, background fluorescence of most samples was overcome by adjusting the size of the confocal aperture. However, a smaller aperture did not solve the persistent problem with obtaining a strong enough Raman signal to produce silica peaks in the spectra.

The Raman spectra of most of the phytoliths examined had rounded peaks that appeared to be artefacts of the instrument (Fig. 6, red and blue lines). These peaks were present in all 
phytolith samples (but not aluminum blanks or air) and do not appear to be correlated with phytolith silica or carbon. Phytoliths that were heated in a muffle furnace to create a temperature gradient from 20 to $600^{\circ} \mathrm{C}$ with the expectation that heat would alter their silica or graphite peaks showed no reliable changes to their Raman spectra. Heating did not generally darken the phytoliths and rarely caused any change to the phytolith spectra. Focusing on tiny dark spots (assumed to be occluded carbon, although recent research by Alexandre et al. (2015) casts doubt on this assumption) inside short cells heated to $500-600^{\circ} \mathrm{C}$ produced the expected graphite peaks in $<2 \%$ of the phytoliths examined. Also, finding and focusing on small regions within short cells was very difficult.

Raman analysis of visually dark phytoliths from plant leaves that were burned in the laboratory as well as those collected in the field after the control burn showed that $96 \%$ had the distinctive graphite peaks at wavenumbers 1372 and 1583 (Figure 6, green line). However, tests of clear phytoliths adjacent to burned phytoliths on articulated phytolith structures (Fig. 4C) revealed that clear phytoliths lacked the graphite peaks. This suggests the graphite peaks may not be due to heating of occluded carbon inside the phytolith but rather to carbon adsorbed to the phytolith surface during combustion.

A sample of processed mascareignite, a mineral assumed to have been formed by burning bamboo and found to have graphite peaks by Pironon et al. (2001), was tested. Despite repeated attempts, only the spectra of a small percentage of darkened phytoliths showed the expected graphite peaks; non-darkened phytoliths had no peaks. Extensive chemical processing used to purify the mascareignite may have removed most of the adsorbed carbon from visually-darkened burned phytoliths, leading to a weak Raman carbon signal. Only one clear mascareignite phytolith (Figure 6, black line) showed the pattern of peaks expected for phytolith silica (Pironon 
et al. 2001; Watling et al. 2011). It is unclear why this particular phytolith showed such a strong signal while others did not. Because heated but non-darkened phytoliths did not have graphite peaks, we also looked for subtle shifts in wavenumber that might occur due to heating of the silica in phytoliths. There were no consistent changes in silica peaks at any of the heating temperatures examined.

The expected graphite peaks were consistently present in Raman spectra of obviously darkened phytoliths from burned leaf material and in soil samples (classified as positively burned in the burned phytolith coloration study). Raman spectra of phytoliths that were not clearly darkened (classified as possibly burned rather than positively burned in the burned phytolith coloration study) very rarely showed graphite peaks, suggesting that their altered appearance was not due to burning but rather to weathering in the soil. It is possible that some of these phytoliths were exposed to fire and darkened with carbon adsorbed to the surface immediately after the fire but biological and chemical weathering of the phytolith surface eventually removed this carbon, leading to an altered phytolith that does not have a graphite Raman signal. These findings reiterate the need for considerably more research to understand the effects of weathering on burned phytoliths.

In summary, the Raman approach to identifying burned phytoliths, while much more time-consuming and expensive, performed no better than the phytolith coloration approach in our study. Only obviously darkened phytoliths consistently showed the graphite peaks expected from burning. Raman spectra of phytoliths that were heated up to $600^{\circ} \mathrm{C}$ but with no obvious dark color showed no graphite peaks. These results suggest that Raman graphite peaks are not generated from the occluded carbon in phytoliths that undergoes changes with heating but rather from the carbon adsorbed by phytoliths exposed to open flames. Thorough cleaning of burned 
phytoliths during processing (known to have been applied to the mascareignite sample), and/or extended weathering in the soil environment, may remove most of the adsorbed carbon to a level below the detection capability of most Raman instruments.

\section{Conclusions}

Phytolith analysis can be an essential component of multidisciplinary studies in paleoecology and archaeology, particularly in grassland or other environments dominated by high phytolith-producing plants. Soil phytolith percent weight data can be very useful for determining long-term vegetation at a site. In Californian soils, high soil phytolith concentration usually means there has been long-term grass-dominated grassland. Absolute counts of phytolith morphotypes can give insight into the presence or dominance of individual taxa. For example, high grass phytolith content in an archaeological site means grasses were extensively utilized by native people in some way, perhaps as food or fuel. When synergistically combined with other lines of evidence at sites such as QVCP, powerful interpretations are possible, in this case showing conclusively that the native population almost certainly used frequent anthropogenic fire to maintain grass-dominated grassland.

In this study, we attempted to extend the utility of phytolith analysis by using the analysis of burned phytoliths in the soil to estimate fire frequency at a site. Unfortunately, none of the approaches tested in this study and previously reported in the literature to distinguish individual burned phytoliths from unburned phytoliths were reliable enough to be useful in estimating past grassland fire regimes in typical soil conditions:

a. The phytolith coloration approach, distinguishing burned phytoliths through their altered color, successfully identified as positively burned the vast majority of 
phytoliths from plant leaf material burned with an open flame, both in the lab and from a recent prescribed burn in the field. Phytoliths that were heated in a muffle furnace to grassland fire temperatures but not exposed to direct flame could not be distinguished. However, there were few obviously darkened soil phytoliths found at the deergrass site in McCabe Canyon or at other grassland sites sampled in Pinnacles NP, or indeed at any of the hundreds of grassland sites examined for phytoliths anywhere in California, even at sites expected to have had a long history of frequent native burning. Instead, many soil phytoliths have altered, rather than darkened, color and/or texture. This suggests that darkened, burned phytoliths may be visually altered, either becoming slightly yellowed, light brown, more opaque or with increasing granular texture as they weather after they are deposited in the soil. This approach holds some promise for reconstructing grassland fire regimes if weathered burned phytoliths can be reliably distinguished from weathered unburned phytoliths; considerable additional research is required to determine whether this is possible.

b. The refractive index approach, distinguishing heated or burned phytoliths through changes in the RI due largely to decreased water content, is dependent on fire intensity and not accurate at the relatively low temperatures typical of grassland fires. The effectiveness of the approach is also compromised by rehydration and phytolith aging effects.

c. The Raman spectroscopic approach, distinguishing individual burned phytoliths through heat-induced changes to occluded carbon, was only able to identify phytoliths that were visually darkened from burning in an open flame, suggesting 
the carbon measured by the Raman instrument is external carbon adsorbed during a fire rather than internal carbon altered by heating.

Since the technique was first suggested almost 30 years ago (Piperno 2006), visual identification of burned phytoliths has been increasingly used in the literature to document fire in a variety of environments (Kealhofer 1996; Boyd 2002; Gu et al. 2008; Morris et al. 2010; Cordova et al. 2011; Garnier et al. 2012; McMichael et al. 2012; Jones et al. 2013; Aleman et al. 2014; Selkin et al. 2015). However, no researchers to date have adequately addressed the issue of distinguishing burned from unburned phytoliths in a typical soil phytolith assemblage that includes phytoliths with a wide range of ages and degrees of weathering. Publications associated with this research usually have a photograph of only a typical darkened phytolith that appears exactly like phytoliths extracted in our study from ash resulting from laboratory burning or prescribed burning of leaf material. Unfortunately, very few phytoliths found in California soils fit this idealized image. It is not clear whether researchers were counting only those phytoliths that were clearly darkened or whether they were also counting those phytoliths that had some alteration of color or texture. The inability to confidently and reliably identify a burned phytolith in a soil assemblage was a major setback for this study, and it is unlikely previous researchers did not face similar challenges. There needs to be an explicit examination of this issue, including further research to clarify which weathered phytoliths should be counted as burned, as well as a survey of work by previous authors to determine which altered phytolith types were included in their counts, with publication of both positive and negative results.

Although the results of this study suggest burned and unburned phytoliths cannot be reliably discriminated at present, further research is warranted because the ability to do so would contribute substantially to phytolith research in archaeology and paleoecology. For example, 
analysis of burned phytoliths at archaeological sites could elucidate cultural burning practices in sites that lack macrobotanical remains. Sites with burned arboreal phytoliths that lack burned phytoliths from herbaceous plants would indicate use of wood as the primary fuel, while sites with high proportions of burned phytoliths from herbaceous plants would indicate use of dung fuel. Analysis of burned phytoliths can also clarify site formation and transformational processes. In chronologically-layered non-archaeological sediments, quantitative estimates of changes in fire frequency from both natural and anthropogenic causes could be calculated from changes in the proportion of burned to unburned phytoliths.

\section{Acknowledgements}

This project was financially supported by the California Department of Parks and Recreation, the National Science Foundation (BCS-0912162 and CHE-1314073), the Gordon and Betty Moore Foundation through the Berkeley Initiative in Global Change Biology, and the Joint Fire Science Program (Project ID 10-1-09-3). We thank the Amah Mutsun Tribal Band for their continued support and collaboration in our team's archaeological and environmental research in the Quiroste Valley Cultural Preserve. We also thank California Department of Parks and Recreation staff facilitating access and collections, including District Archaeologist Mark Hylkema, District Ecologist Tim Hyland, and Año Nuevo State Park head ranger Terry Kiser. Thanks also to Kent

Lightfoot for facilitating formation of the interdisciplinary team, as well as Christine Hastorf and the UC Berkeley Archaeological Research Facility for providing access to laboratory space and equipment. For assistance with the Raman spectroscopy instruments, we thank Alan Hicklin at the Spectral Imaging Facility at UC Davis and Dan Borchardt at the UC Riverside Analytical Chemistry Instrumentation Facility (Dilor XY Raman instrument funded by NSF grant CHE- 
9709036). Thanks also to Brent Johnson at Pinnacles National Park for study coordination and field support, and Anne Alexandre of CEREGE for providing mascareignite samples.

\section{References}

Aleman, J.C., Canal-Subitani, S., Favier, C., Bremond, L., 2014. Influence of the local environment on lacustrine sedimentary phytolith records. Palaeogeography, Palaeoclimatology, Palaeoecology 414, 273-283.

Alexandre, A., Basile-Doelsch, I., Delhaye, T., Borshneck, D., Mazur, J.C., Reyerson, P., Santos, G.M., 2015. New highlights of phytolith structure and occluded carbon location: 3-D X-ray microscopy and NanoSIMS results. Biogeosciences 12, 863-873.

Blecker, S.W., McCulley, R.L., Chadwick, O.A., Kelly, E.F., 2006. Biologic cycling of silica across a grassland bioclimosequence. Global Biogeochemical Cycles 20, GB3023.

Boyd, M., 2002. Identification of anthropogenic burning in the paleoecological record of the northern prairies: a new approach. Annals of the Association of American Geographers 92, 471-487.

Cabanes, D., Weiner, S., Shahack-Gross, R., 2011. Stability of phytoliths in the archaeological record: a dissolution study of modern and fossil phytoliths. Journal of Archaeological Science 38, 2480-2490.

Cordova, C.E., Johnson, W.C., Mandel, R.D., Palmer, M.W., 2011. Late Quaternary environmental change inferred from phytoliths and other soil-related proxies: case studies from the central and southern Great Plains, USA. Catena 85(2), 87-108.

Cowart, A.D., 2014. Paleoenvironmental Change in Central California in the Late Pleistocene and Holocene: Impacts of Climate Change and Human Land Use on Vegetation and Fire 
Regimes. Unpublished PhD dissertation, Department of Geography, University of California, Berkeley.

Cowart, A.D., Byrne, R., 2013. A paleolimnological record of Late Holocene vegetation change from the Central California Coast. California Archaeology 5, 337-352.

Cuthrell, R.Q., 2013a. An Eco-Archaeological Study of Late Holocene Indigenous Foodways and Landscape Manage-ment Practices at Quiroste Valley Cultural Preserve, San Mateo County, California. Unpublished Ph.D. dissertation, Department of Anthropology, University of California, Berkeley.

Cuthrell, R.Q., 2013b. Archaeobotanical evidence for indigenous burning practices and foodways at CA-SMA-113. California Archaeology 5, 265-290.

Cuthrell, R.Q., Hylkema, M.G., Collins, L., 2013. Natural resources, geomorphology, and archaeology of site CA-SMA-113 in Quiroste Valley Cultural Preserve, California. California Archaeology 5, 247-264.

Elbaum, R., Weiner, S., Albert, R.M., Elbaum, M., 2003. Detection of burning of plant materials in the refractive indices of siliceous phytoliths. Journal of Archaeological Science 30, $217-$ 226.Evett, R.R., Bartolome, J.W., 2013. Phytolith evidence for the extent and nature of prehistoric Californian grasslands. The Holocene 23, 1644-1649.

Evett, R.R., Cuthrell, R.Q., 2013. Phytolith evidence for a grass-dominated prairie landscape at Quiroste Valley on the central coast of California. California Archaeology 5, 319-335.

Evett, R.R., Cuthrell, R.Q., 2015. A conceptual framework for a computer-assisted, morphometric-based phytolith analysis and classification system. Journal of Archaeological Science 10.1016/j.jas.2015.09.003Evett, ～R.R., Woodward, ～R.A., Harrison, W., Suero, J., Raggio, P., Bartolome, J.W., 2006. Phytolith evidence for the lack of a grass understory in 
a Sequoiadendron giganteum (Taxodiaceae) stand in the central Sierra Nevada, California. Madrono 53, 351-363.

Evett, R.R., Franco-Vizcaino, E., Stephens, S.L. 2007. Phytolith evidence for the absence of a prehistoric grass understory in a Jeffrey pine-mixed conifer forest in the Sierra San Pedro Martir, Mexico. Canadian Journal of Forest Research 37, 306-317.

Evett, R.R., Dawson, A., Bartolome, J.W., 2013. Estimating vegetation reference conditions by combining historical source analysis and soil phytolith analysis at Pepperwood Preserve, Northern California Coast Ranges, U.S.A. Restoration Ecology 21, 464-473.

Farris, C.A., Baisan, C.H., Falk, D.A., Yool, S.R., Swetnam, T.W., 2010. Spatial and temporal corroboration of a fire-scar-based fire history in a frequently burned ponderosa pine forest. Ecological Applications 20, 1598-1614.

Fishkis, O., Ingwersen, J., Lamers, M., Denysenko, D., Streck, T., 2010. Phytolith transport in soil: a field study using fluorescent labelling. Geoderma 157, 27-36.

Ford, L.D., Hayes, G.F., 2007. Northern Coastal Scrub and Coastal Prairie. In: Stromberg, M.R., Corbin, J.D., D'Antonio, C.M. (Eds.), California Grasslands: Ecology and Management, University of California Press, Berkeley, pp. 180-207.

Garnier, A., Neumann, K., Eichhorn, B., Lespez, L., 2012. Phytolith taphonomy in the middle-to late-Holocene fluvial sediments of Ounjougou (Mali, West Africa). The Holocene 23, 416431.

Gibson, D.J., Hartnett, D.C., Merrill, G.L.S., 1990. Fire temperature heterogeneity in contrasting fire prone habitats: Kansas Tallgrass Prairie and Florida Sandhill. Bulletin of the Torrey Botanical Club 117, 349-356. 
Gifford-Gonzalez, D., Boone, C.M., Reid, R.E., 2013. The fauna from Quiroste: insights into indigenous foodways, culture, and land modification. California Archaeology 5, 291-317.

Gu, Y., Pearsall, D.M., Xie, S., Yu, J., 2008. Vegetation and fire history of a Chinese site in southern tropical Xishuangbanna derived from phytolith and charcoal records from Holocene sediments. Journal of Biogeography 35, 325-341.

Jones, S.E., Hunt, C.O., Barton, H., Lentfer, C.J., Reimer, P.J., 2013. Forest disturbance, arboriculture and the adoption of rice in the Kelabit Highlands of Sarawak, Malaysian Borneo. The Holocene 23, 1528-1546.

Kealhofer, L., 1996. The human environment during the terminal Pleistocene and Holocene in northeastern Thailand: preliminary phytolith evidence from Lake Kumphawapi. Asian Perspectives 35, 229-254.

Kelly, E.F., 1990. Methods for extracting opal phytoliths from soil and plant material. Internal Report, Department of Agronomy, Colorado State University, Fort Collins, USA.

Lightfoot, K.G., Cuthrell, R.Q., Boone, C.M., Byrne, R., Chavez, A.S., Collins, L., Cowart, A., Evett, R.R., Fine, P.V.A., Gifford-Gonzalez, D., Hylkema, M.G., Lopez, V., Misiewicz, T.M., Reid, R.E.B., 2013. Anthropogenic burning on the Central California Coast in Late Holocene and Early Historical times: findings, implications, and future directions. California Archaeology 5, 371-390.

Madella, M., Lancelotti, C., 2012. Taphonomy and phytoliths: a user manual. Quaternary International 275, 76-83.

McMichael, C.H., Piperno, D.R., Bush, M.B., Silman, M.R., Zimmerman, A.R., Raczka, M.F., Lobato, L.C., 2012. Sparse pre-Columbian human habitation in western Amazonia. Science 336, 1429-1431. 
Meunier, J.D., Colin, F., Alarcon, C., 1999. Biogenic silica storage in soils. Geology 27, 835838.

Morris, L.R., Ryel, R.J., West, N.E., 2010. Can soil phytolith analysis and charcoal be used as indicators of historic fire in the pinyon-juniper and sagebrush steppe ecosystem types of the Great Basin Desert, USA? The Holocene 20, 105-114.

Parr, J.F., 2006. Effect of fire on phytolith coloration. Geoarchaeology 21, 171-185.

Piperno, D.R., 2006. Phytoliths: A Comprehensive Guide for Archaeologists and Paleoecologists. AltaMira Press, Lanham, Maryland.

Pironon, J., Meunier, J.D., Alexandre, A., Mathieu, R., Mansuy, L., Grosjean, A., Jarde, E., 2001. Individual characterization of phytoliths: experimental approach and consequences on paleoenvironmental understanding. In: Meunier, J.D., Colin, F. (Eds.), Phytoliths: Applications in Earth Sciences and Human History. A.A. Balkema Publishers, Lisse, Netherlands, pp. 329-341.

Selkin, P.A., Stromberg, C.A.E., Dunn, R., Kohn, M.J., Carlini, A.A., Davies-Vollum, K.S., Madden, R.H., 2015. Climate, dust, and fire across the Eocene-Oligocene transition, Patagonia. Geology 43, 567-570.

Siregar, A., Kleber, M., Mikutta, R., Jahn, R., 2005. Sodium hypochlorite oxidation reduces soil organic matter concentrations without affecting inorganic soil constituents. European Journal of Soil Science 56, 481-490.

Stephens, S.L., Martin, R.E., Clinton, N.E., 2007. Prehistoric fire area and emissions from California's forests, woodlands, shrublands, and grasslands. Forest Ecology and Management $351,205-216$. 
Striplen, C.J., 2014. A Dendroecology-based Fire History of Coast Redwoods (Sequoia sempervirens) in Central Coastal California. Unpublished Ph.D. dissertation, Department of Environmental Science, Policy, and Management, University of California, Berkeley.

Watling, K.M., Parr, J.F., Rintoul, L., Brown, C.L., Sullivan, L.A., 2011. Raman, infrared and XPS study of bamboo phytoliths after chemical digestion. Spectrochimica Acta Part AMolecular and Biomolecular Spectroscopy 80, 106-111.

Wilding, L.P., 1967. Radiocarbon dating of biogenetic opal. Science 156, 66-67.

Wyche, G., 2012. High resolution paleothermometry using biogenic silica: a feasibility study. Unpublished MS Thesis, University of South Carolina.

\section{List of Figures}

Fig. 1. Locations of Quiroste Valley Cultural Preserve and McCabe Canyon in California.

Fig. 2. Phytolith sampling locations and phytolith content (\% dry weight) in near-surface soils at sites located on a $500 \mathrm{~m}$ grid overlaid on the coastal portion of Whitehouse Creek watershed. White numbers indicate soil phytolith percentage. Grey circles indicate sampling locations, with symbol size scaled according to soil phytolith content. Red line - Whitehouse Creek watershed boundary. Blue line - Quiroste Valley Cultural Preserve boundary.

Fig. 3. Post-burn close-up photograph of one of the burned plots at McCabe Canyon with the aluminum tag that was painted with temperature-sensitive lacquers. Note the wide range in the nature and color of the remaining vegetation and ash. Laboratory experiments suggest this indicates there was a very wide range of peak temperatures experienced at a small scale during the burn. 
Fig. 4. Light microscope images of phytoliths extracted from deergrass ash collected from the soil surface immediately following a prescribed burn at Pinnacles NP (A,B,C) and an ash pit feature at archaeological site CA-SMA-113 in Quiroste Valley (D,E,F). A) Positively burned deergrass phytoliths. There is a gradient in coloration effects from burning, from totally dark, opaque elongates, partially darkened saddle short cells, and a few lightly colored phytoliths. B) A positively burned appendage phytolith contrasted with an unburned appendage. Note the incomplete coloration of many elongates. C) Burned deergrass leaf epidermis. Short cells are typically the first to show color changes after burning, while many elongates commonly show only light or partial coloration . D) Highly weathered elongate. This phytolith is classified as possibly burned because there is some darkening that may have been caused by burning even though it scarcely resembles an unweathered, burned phytolith; conversely, darkening may be due to taphonomic changes of an unburned phytolith subjected to weathering. E) Darkened, weathered elongate on the left classified as positively burned because the color resembles a modern burned phytolith; highly weathered elongate on the right is classified as unburned even though there are subtle changes in color and opacity. F) Problematic weathered appendage phytoliths. Both appendages have a very subtle brown tint and granulation that may indicate burning but may be the result of changes due to processing chemicals or weathering.

Fig. 5. Percentage of saddle short cell phytoliths with refractive index (RI) above 1.44 found after ashing deergrass leaf samples at various temperatures in a muffle furnace, and after ashed samples were rehydrated for one week in distilled water.

Fig. 6. Raman spectra of individual phytoliths obtained with the confocal Raman spectrometer at UC-Riverside using a $523 \mathrm{~nm}$ laser. Red and blue lines are typical spectra of almost all phytoliths examined that were not visually dark; peaks are most likely artefacts. The green line 
with the distinctive graphite peaks at wavenumbers 1372 and 1583 is typical of spectra of visually darkened phytoliths. The black line is the spectrum of the only phytolith examined that closely matches the silica pattern described by Pironon et al. (2001).

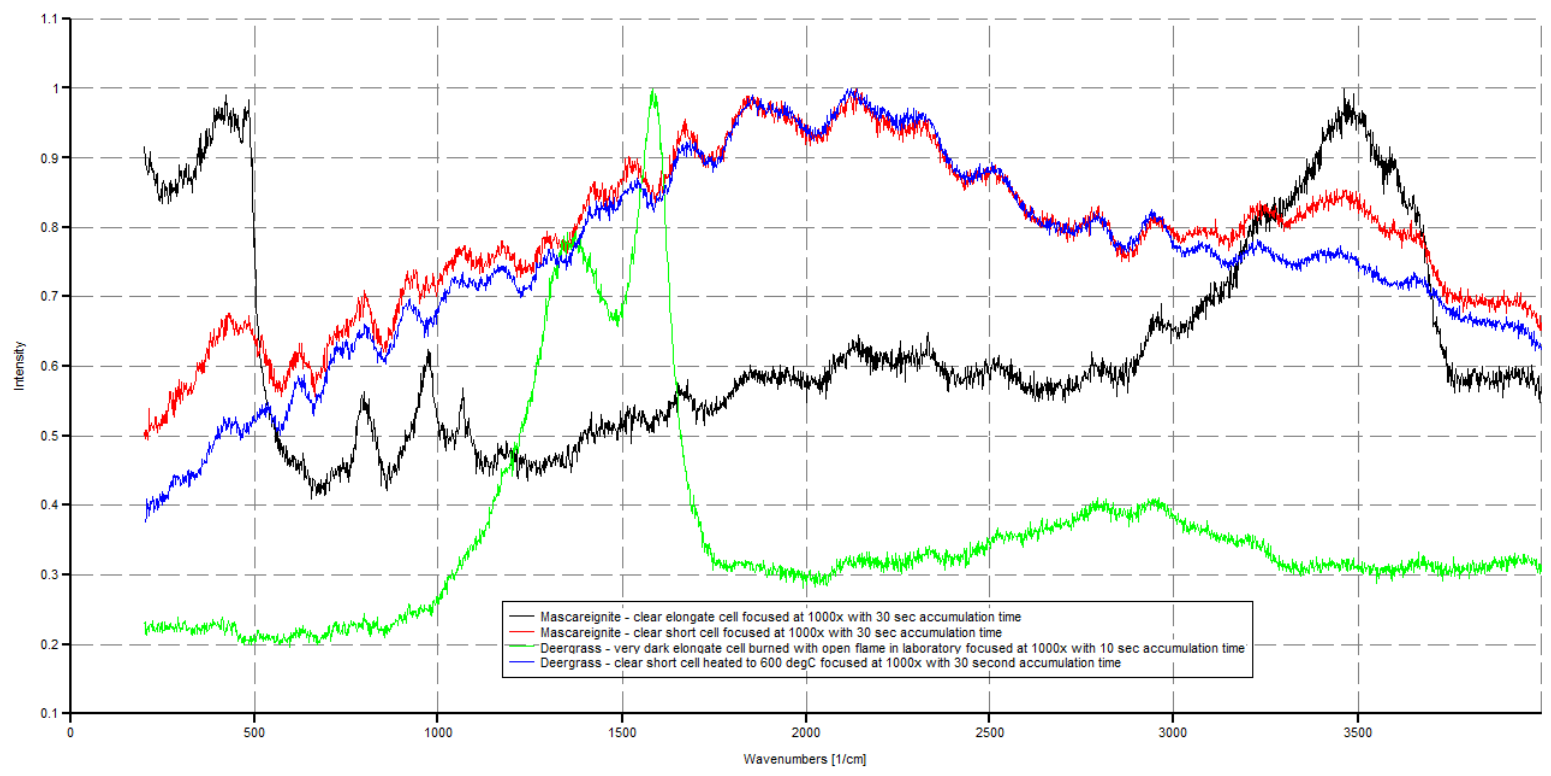




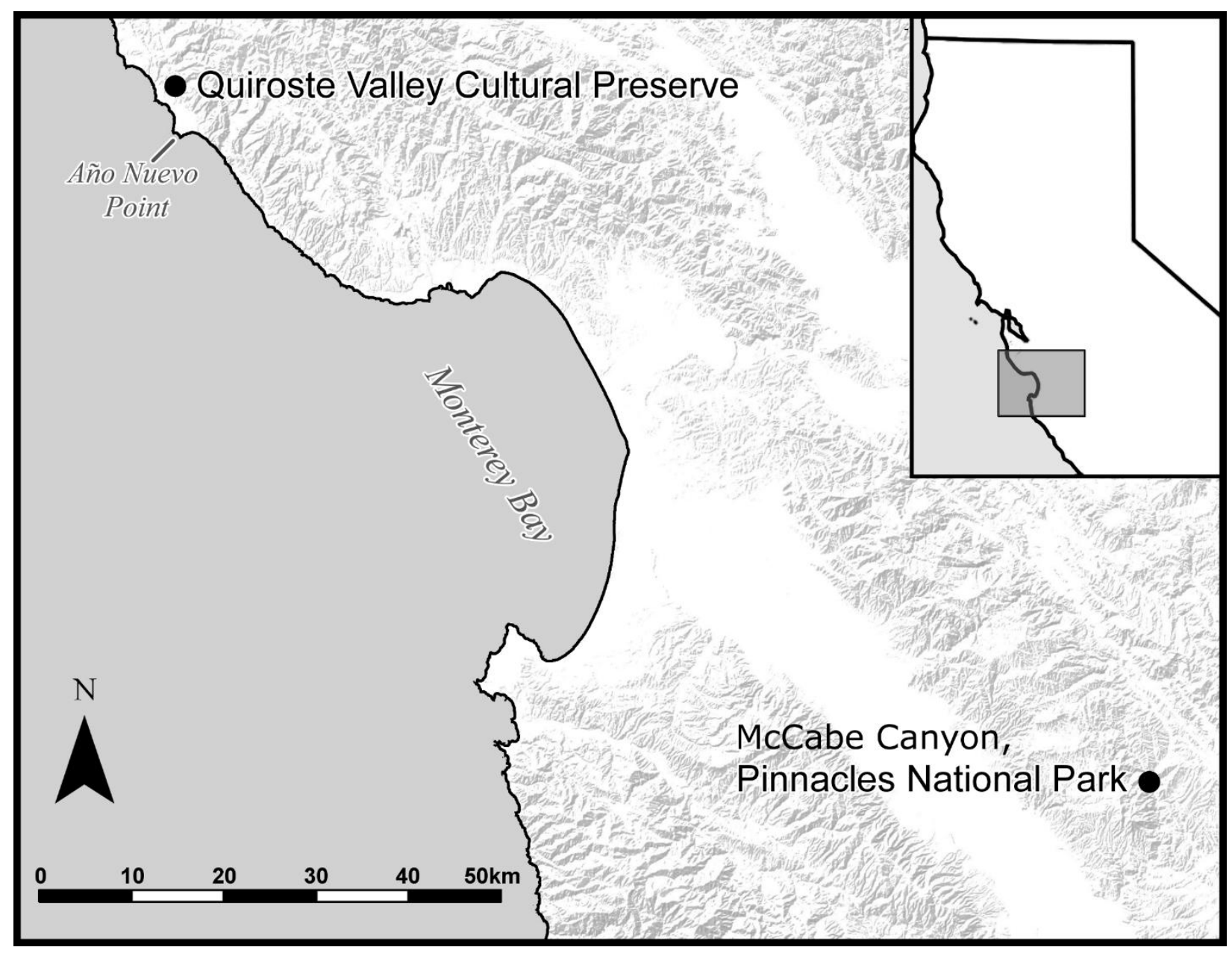




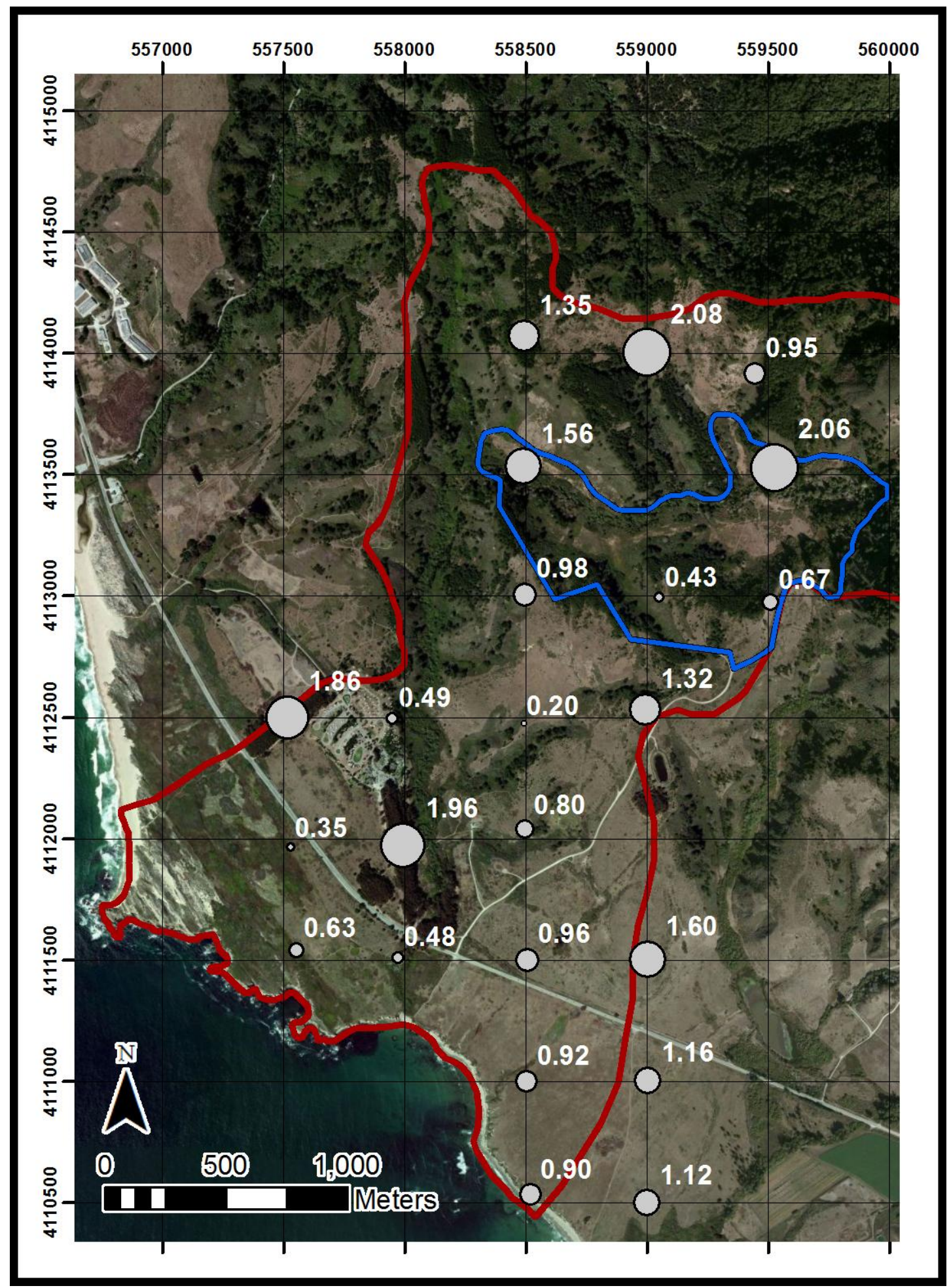




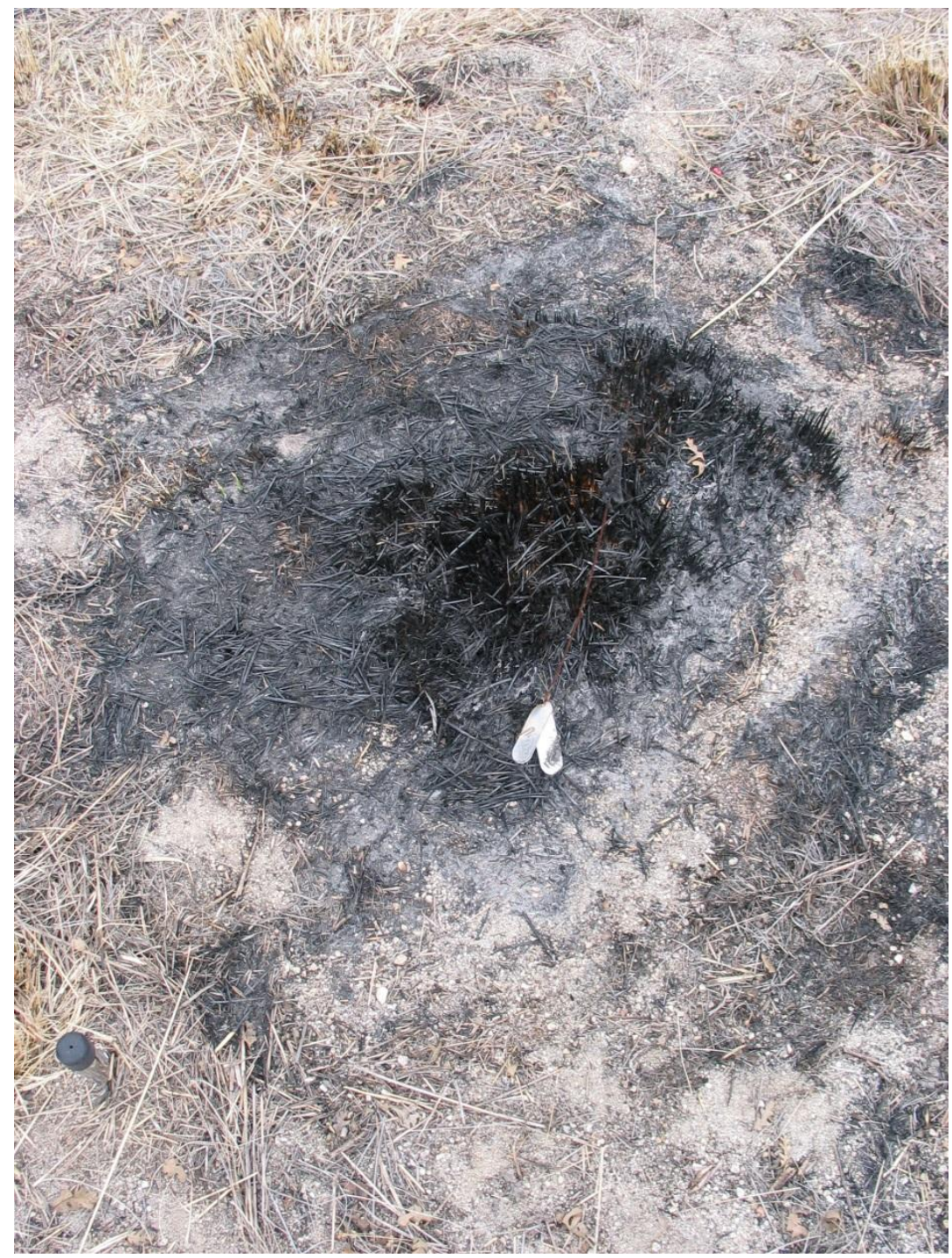



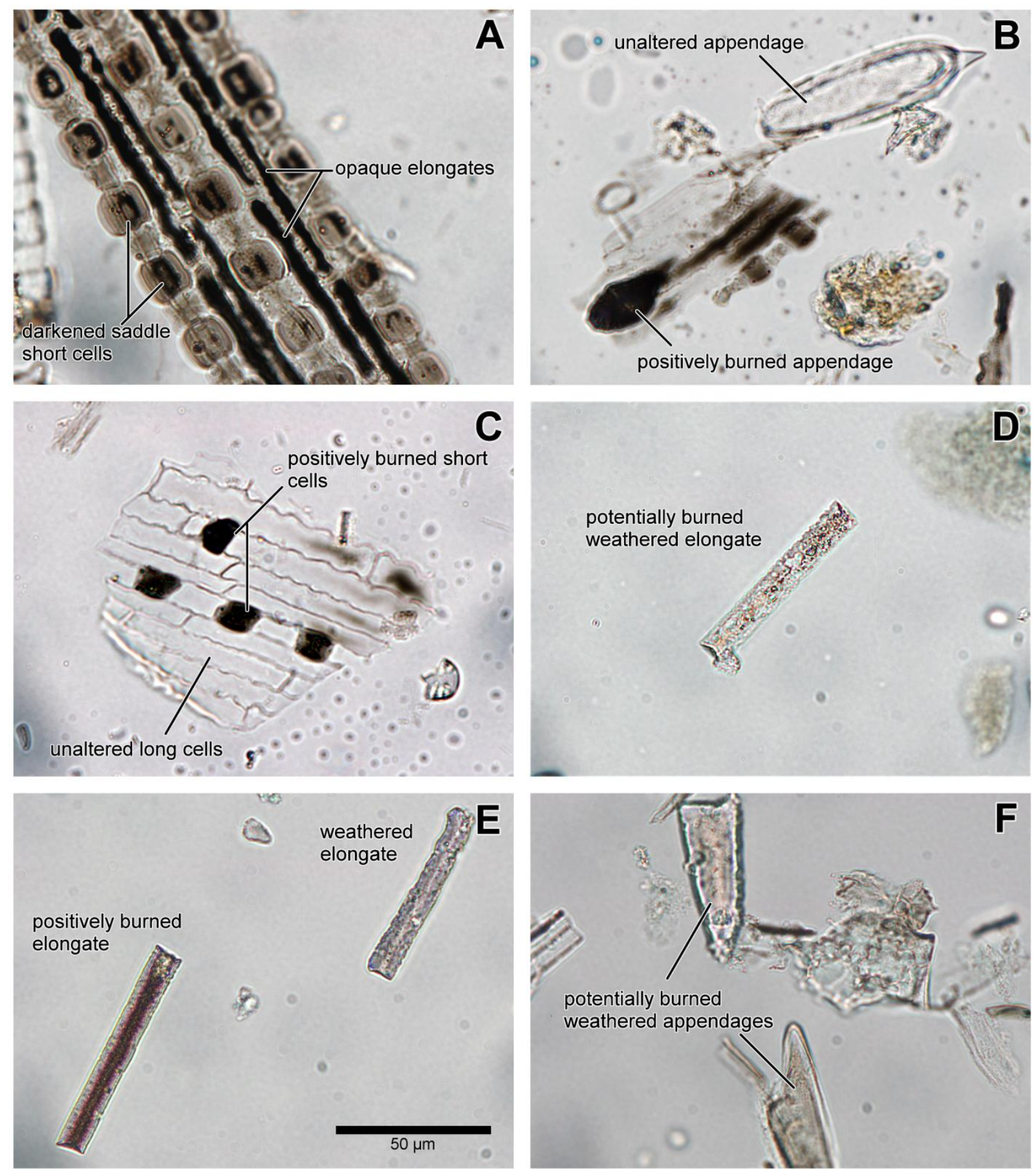


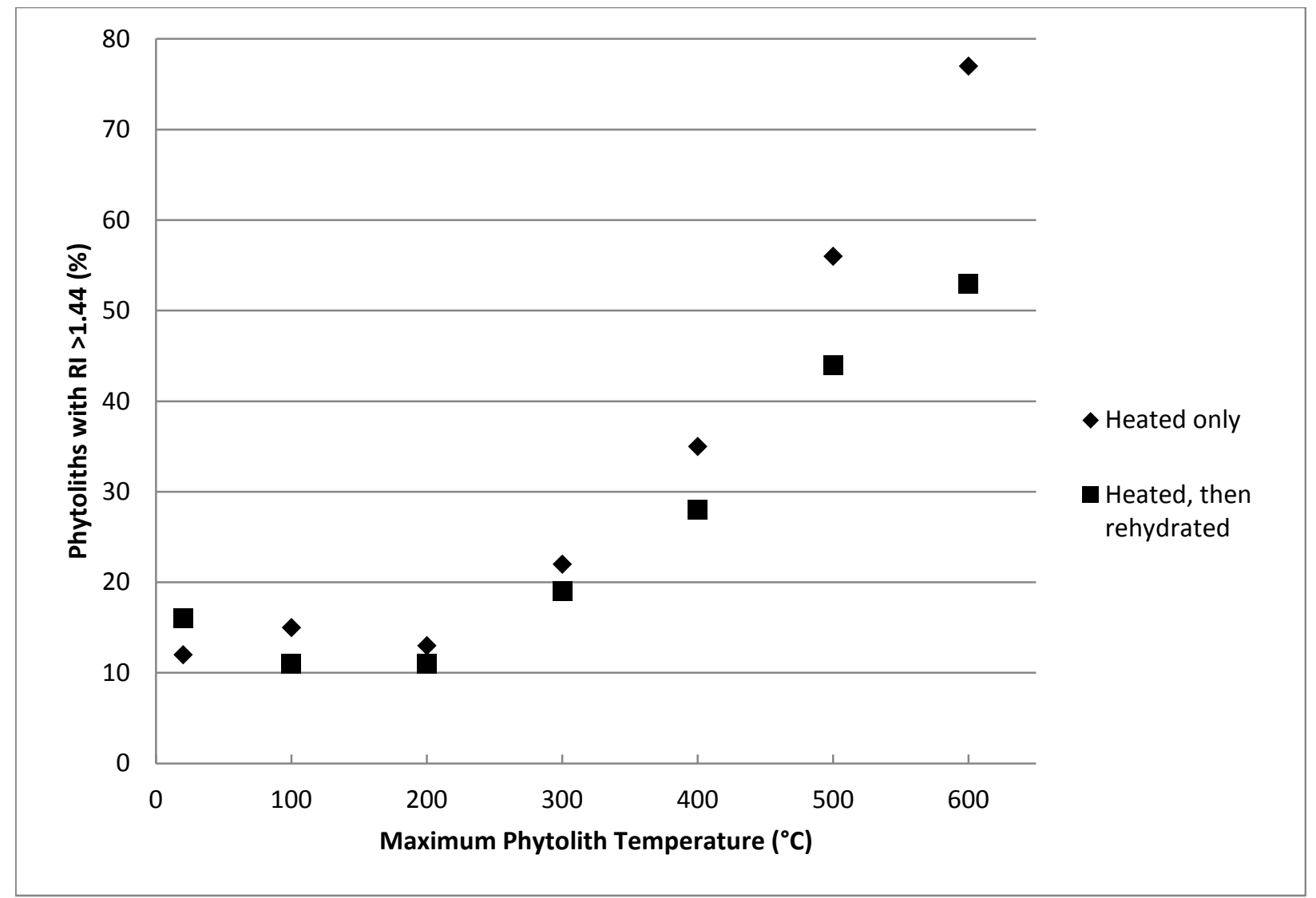




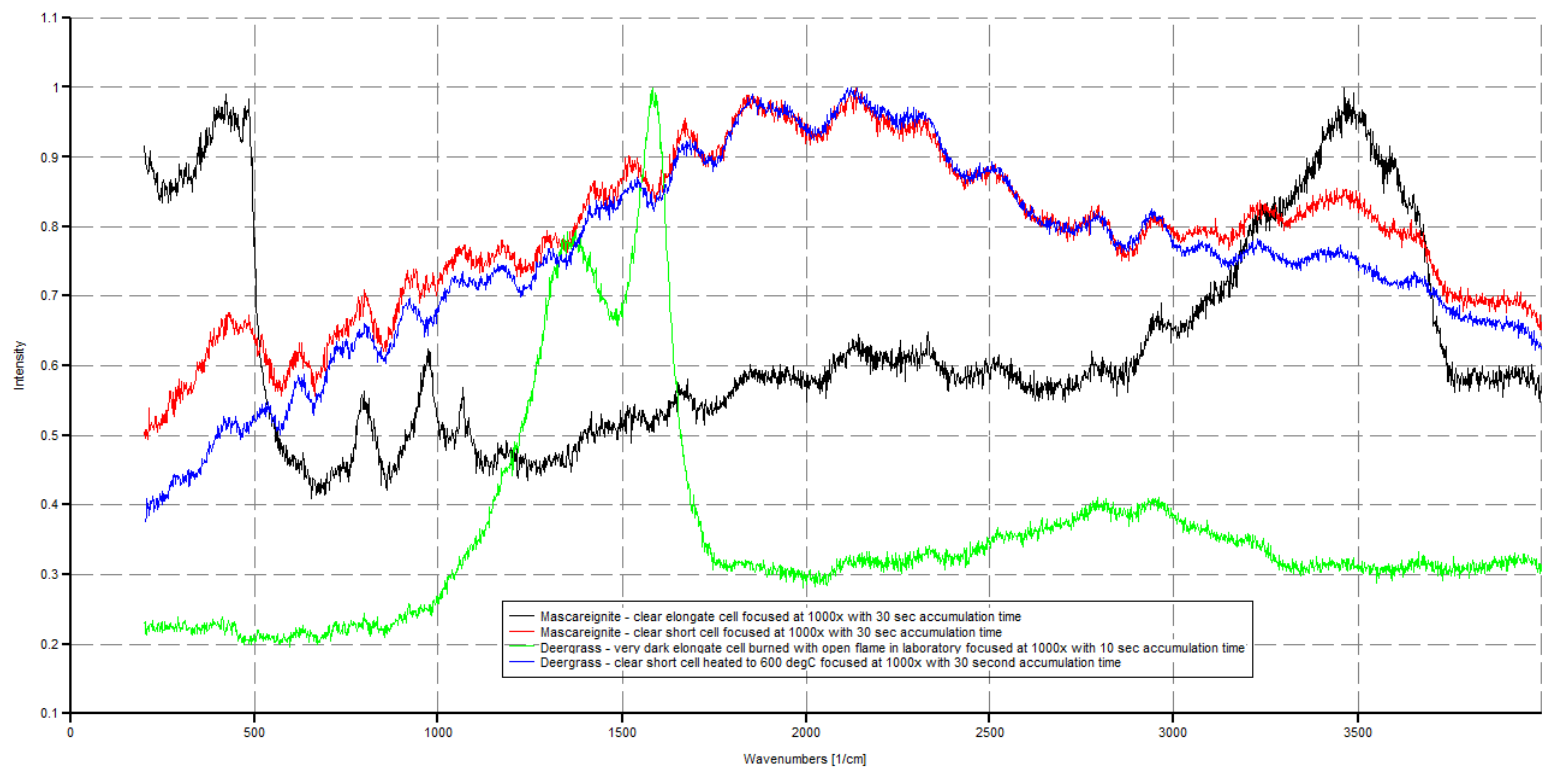


Table 1. Phytolith weight and absolute morphotype counts for surface soil samples from sites on a $500 \mathrm{~m}$ grid surrounding Quiroste Valley.

\begin{tabular}{|c|c|c|c|c|c|c|c|c|c|c|}
\hline UTM East & UTM North & $\begin{array}{c}\text { Current } \\
\text { Vegetation }\end{array}$ & $\begin{array}{c}\text { Phytolith } \\
\text { Weight } \\
(\%)\end{array}$ & $\begin{array}{c}\text { Grass } \\
\text { Rondels } \\
\text { (No./g soil) }\end{array}$ & $\begin{array}{c}\text { Grass } \\
\text { Bilobates } \\
\text { (No./g soil) }\end{array}$ & $\begin{array}{c}\text { Grass } \\
\text { Crenates } \\
\text { (No./g soil) }\end{array}$ & $\begin{array}{c}\text { Total } \\
\text { Grass } \\
\text { Short Cells } \\
\text { (No./g soil) }\end{array}$ & $\begin{array}{l}\text { Elongates } \\
\text { (No./g soil) }\end{array}$ & $\begin{array}{c}\text { Appendages } \\
\text { (No./g soil) }\end{array}$ & $\begin{array}{c}\text { Total } \\
\text { Phytoliths } \\
\text { (No./g soil) }\end{array}$ \\
\hline 557500 & 4111500 & grassland (dunes) & 0.63 & 49874 & 21375 & 28500 & 99748 & 92624 & 14250 & 206622 \\
\hline 557500 & 4112000 & NCS / Douglas fir & 0.35 & 304322 & 43804 & 101441 & 449567 & 251296 & 11527 & 712391 \\
\hline 557500 & 4112500 & eucalyptus forest & 1.86 & 659008 & 171342 & 276783 & 1107134 & 645828 & 39540 & 1792502 \\
\hline 558000 & 4111500 & NCS & 0.48 & 676124 & 142843 & 174586 & 993553 & 447575 & 25394 & 1466522 \\
\hline 558000 & 4112000 & eucalyptus forest & 1.96 & 701321 & 68422 & 547373 & 1317116 & 1111851 & 68422 & 2497389 \\
\hline 558000 & 4112500 & cultivated lawn & 0.49 & 525363 & 26123 & 124810 & 676296 & 519558 & 14513 & 1210367 \\
\hline 558500 & 4110000 & grassland & 0.92 & 1056619 & 396903 & 337904 & 1791426 & 976166 & 80453 & 2848045 \\
\hline 558500 & 4110500 & grassland & 0.90 & 700068 & 287931 & 220183 & 1208182 & 592800 & 45166 & 1846147 \\
\hline 558500 & 4111500 & grassland & 0.96 & 1163978 & 504581 & 229355 & 1897914 & 1026364 & 63073 & 2987351 \\
\hline 558500 & 4112000 & grassland / NCS & 0.80 & 476063 & 105235 & 140313 & 721611 & 461029 & 30067 & 1212707 \\
\hline 558500 & 4112500 & grassland / NCS & 0.20 & 111315 & 61286 & 56283 & 228884 & 61286 & 7504 & 297675 \\
\hline 558500 & 4113000 & grassland & 0.98 & 601356 & 134283 & 151798 & 887437 & 484587 & 87576 & 1459601 \\
\hline 558500 & 4113500 & riparian & 1.56 & 333177 & 83294 & 333177 & 749648 & 791295 & 41647 & 1582590 \\
\hline 558500 & 4114000 & NCS / Douglas fir & 1.35 & 574399 & 165938 & 446755 & 1187092 & 663750 & 25529 & 1876371 \\
\hline 559000 & 4110500 & grassland & 1.12 & 1147485 & 580262 & 293391 & 2021139 & 1186604 & 104317 & 3312060 \\
\hline 559000 & 4111000 & grassland & 1.16 & 1199966 & 655154 & 68964 & 1924083 & 1110313 & 110342 & 3144738 \\
\hline 559000 & 4111500 & grassland & 1.60 & 1395601 & 363239 & 229414 & 1988253 & 1252217 & 76471 & 3316942 \\
\hline 559000 & 4112500 & NCS & 1.32 & 839378 & 349048 & 324116 & 1512543 & 706407 & 66485 & 2285435 \\
\hline 559000 & 4113000 & NCS & 0.43 & 584803 & 48734 & 143493 & 777030 & 454847 & 37904 & 1269781 \\
\hline 559000 & 4114000 & grassland / NCS & 2.08 & 562236 & 156177 & 291530 & 1009943 & 770472 & 93706 & 1874120 \\
\hline 559500 & 4113000 & grassland / Douglas fir & 0.67 & 372835 & 75575 & 216647 & 665057 & 377873 & 35268 & 1078198 \\
\hline 559500 & 4113500 & NCS & 2.06 & 582577 & 83225 & 693544 & 1359346 & 998703 & 41613 & 2399662 \\
\hline 559500 & 4114000 & NCS & 0.95 & 449308 & 377827 & 428885 & 1256020 & 908827 & 91904 & 2256751 \\
\hline
\end{tabular}

NCS $=$ northern coastal scrub 
Table 2. Percentage of phytoliths identified as positively burned (black, dark gray or dark brown), or possibly burned (altered in some way to resemble burned), in samples from various experimental manipulations and sites ( $N=300$ phytoliths for each sample; $F R I=$ Fire Return Interval).

\begin{tabular}{lcc}
\hline Experimental Manipulation or Sampling Site & $\begin{array}{c}\text { Positively } \\
\text { Burned (\%) }\end{array}$ & $\begin{array}{c}\text { Possibly } \\
\text { Burned (\%) }\end{array}$ \\
\hline Ponderosa pine leaf lab burn & 85 & 5 \\
Deergrass leaf lab burn & 92 & 4 \\
Deergrass leaf unheated $20^{\circ} \mathrm{C}$ & 0 & 0 \\
Deergrass leaf muffle furnace $100^{\circ} \mathrm{C}$ & 0 & 0 \\
Deergrass leaf muffle furnace $200^{\circ} \mathrm{C}$ & 0 & 0 \\
Deergrass leaf muffle furnace $300^{\circ} \mathrm{C}$ & 0 & 0 \\
Deergrass leaf muffle furnace $400^{\circ} \mathrm{C}$ & 3 & 1 \\
Deergrass leaf muffle furnace $500^{\circ} \mathrm{C}$ & 8 & 2 \\
Deergrass leaf muffle furnace $600^{\circ} \mathrm{C}$ & 6 & 2 \\
Pinnacles NP prescribed burn ash samples (mean, 12 plots) & 76 & 6 \\
Pinnacles NP pre-prescribed burn soil samples (mean, 12 plots) & 2 & 40 \\
Pinnacles NP post-prescribed burn soil samples (mean, 12 plots) & 7 & 40 \\
Pinnacles NP cut bank below prescribed burn site at 30cm depth & 7 & 26 \\
Pinnacles NP grassland soil samples (mean, 20 sites) & 3 & 33 \\
Pinnacles NP burned grassland near entrance & 6 & 70 \\
Quiroste Valley ash pit N25W103 020 & 11 & 51 \\
Mascareignite from Reunion Island & 6 & 43 \\
Rincon Mountains soil samples from sites with FRI >60 yr (mean, 2 sites) & 3 & 21 \\
Rincon Mountains soil samples from sites with FRI 60 yr (mean, 2 sites) & 5 & 34 \\
Rincon Mountains soil samples from sites with FRI 30 yr (mean, 2 sites) & 8 & 32 \\
Rincon Mountains soil samples from sites with FRI 20 yr (mean, 2 sites) & 4 & 39 \\
Rincon Mountains soil samples from sites with FRI 15 yr (mean, 2 sites) & 4 & 45 \\
Rincon Mountains soil samples from sites with FRI <15 yr (mean, 3 sites) & 8 & \\
\hline
\end{tabular}

